\title{
SCIENTIFIC LITERACY SKILL PESERTA DIDIK DENGAN MODEL PEMBELAJARAN FREE INQUIRY PADA MATERI KEANEKARAGAMAN HAYATI
}

\author{
Wulan Puja Santika $^{\left.1^{*}\right)}$, Suharsono ${ }^{2)}$, Liah Badriah ${ }^{3)}$ \\ 1,2,3) Jurusan Pendidikan Biologi, FKIP, Universitas Siliwangi \\ *email:wulanpuja96@gmail.com
}

\section{Diterima 18 September 2020 disetujui 18 Okober 2020 diterbitkan 14 November 2020}

\begin{abstract}
The purpose of this study was to determine the effect of the free inquiry learning model on students' scientific literacy skills on the material of biodiversity. This study was conducted from July to October 2019. The research method used true experimental with a population of all class X SMA Negeri 6 Tasikmalaya as many as 7 classes. with 248 students. The sample used is 2 classes taken by cluster random sampling, namely class $X$ MIPA-5 as the control class and class X MIPA-6 as the experimental class. The research instrument in the form of a scientific literacy skill test in the form of multiple choices on biodiversity material, amounting to 48 questions. The data analysis technique used is the parametric statistical test ( $t$ test). Based on the results of the study, it can be concluded that there is an effect of the free inquiry learning model on students' scientific literacy skills on biodiversity material in class X SMA Negeri 6 Tasikmalaya in the 2019/2020 academic year.
\end{abstract}

Keywords: free inquiry, scientific literacy skills, biodiversity

\section{PENDAHULUAN}

Indonesia masa kini sedang melakukan pengembangan dalam bidang pendidikan yang dihadapkan ada sejumlah tantangan yang semakin berat. Salah satu tantangan nyata tersebut adalah bahwa Pendidikan hendaknya mampu menghasilkan sumber daya manusia yang memiliki kompetensi yang utuh.

Sementara itu, pemberlakuan kurikulum 2013 menuntut sejumlah perubahan mendasar pada proses pembelajaran yang berlangsung di persekolahan. Kurikulum 2013 juga harus membiasakan siswa untuk beraktivitas dan mencari pengetahuan sendiri agar wawasannya lebih luas. Salah satu cara untuk mengembangkan wawasan peserta didik lebih luas yaitu dengan membangun keterampilan literasi sains.

Upaya untuk membangun keterampilan literasi sains di dunia pendidikan memerlukan komitmen yang tinggi dari setiap praktisi pendidikan sains. scientific literacy skill juga harus dimiliki peserta didik karena membangun generasi baru yang memiliki pemikiran serta sikap ilmiah. Keterampilan literasi sains penting untuk dikuasai oleh peserta didik dalam kaitannya dengan cara peserta didik itu dapat memahami perkembangan ilmu pengetahuan.

Terlepas dari itu, biologi merupakan salah satu mata pelajaran yang menuntut peserta didik untuk berpikir ilmiah, karena mata pelajaran biologi merupakan sains yang sangat identik sekali dengan research. Materi yang dipelajari adalah makhluk hidup, baik itu yang dapat dilihat secara langsung (makro) atau tidak dapat dilihat secara langsung (mikro). Semua materi pada dasarnya penting, tapi pada materi keanekaragaman hayati di sekolah perlu banyak perbaikan. Salah satunya dengan model inkuiri ditambah belum ada pengukuran Scientific literacy skill tentang materi itu menurut guru mata pelajaran biologi. Juga adanya sinkronisasi unsur saintifik dari materi ini dengan variabel terikat ataupun bebas.

Proses pembelajaran pada dasarnya bertujuan untuk mengembangkan potensi yang dimiliki oleh peserta didik, namun hal ini tidaklah mudah karena proses pembelajaran bukan sekedar menyerap 
informasi saja, tetapi melibatkan berbagai kegiatan yang harus dilakukan salah satunya dalam meningkatkan scientific literacy skill peserta didik sesuai tuntutan kurikulum 2013 yaitu literasi. Untuk mengetahui scientific literacy skill yang baik, peserta didik bukan hanya menguasai pengetahuan berupa fakta atau konsep saja, melainkan peserta didik harus mendapat pengalaman langsung dan bahkan jika memungkinkan menemukan sendiri proses tersebut melalui pendekatan proses mentalnya secara aktif.

Berdasarkan hasil observasi dan wawancara dengan guru mata pelajaran biologi kelas X di SMA Negeri 6 Kota Tasikmalaya pada tanggal 22 Januari 2019, diperoleh keterangan bahwa dalam pelaksanaan pembelajaran biologi masih banyak mengalami kesulitan, diantaranya peserta didik sulit untuk memahami materi pembelajaran yang diajarkan oleh guru khususnya pada materi keanekaragaman hayati, karena proses pembelajaran yang digunakan kurang menarik dan bervariasi.

Sementara itu, dalam proses pembelajarannya peserta didik akan merasa bosan dan jenuh dengan kegiatan belajarnya karena peserta didik hanya cukup menjelaskan konsep-konsep yang ada pada buku ajar atau referensi lain dan proses pembelajaran hanya menyentuh ingatan peserta didik dalam jangka pendek saja serta peserta didik tidak menguasai konsep materi yang telah dipelajarinya, oleh karena itu tidak sedikit peserta didik dalam proses pembelajaran mencari kesibukan lain seperti ngobrol dengan temannya tanpa memperhatikan lagi tugas yang diberikan oleh guru.

Cara mengatasi masalah tersebut, hendaknya guru melakukan inovasi-inovasi dalam penyajian materi pembelajaran sehingga peserta didik menjadi antusias terhadap materi yang disajikan oleh guru. Salah satu cara yang dapat dilakukan yaitu dengan memvariasikan model pembelajaran. Pemilihan model pembelajaran yang dipandang lebih tepat adalah model pembelajaran yang dapat merangsang peserta didik untuk lebih aktif terlibat langsung dalam mengorganisasikan data, memecahkan masalah, menemukan konsep serta memberikan kesempatan pada peserta didik untuk berkreativitas. Salah satu model pembelajaran yang dapat diterapkan yaitu model pembelajaran free inquiry karena adanya sinkronisasi dengan variable terikatnya.

Menurut Kurniasih (2015) Model Pembelajaran free inquiry merupakan model pembelajaran yang bersifat membangun sebuah konsep terhadap peserta didik, guru hanya mengawasi proses pembelajaran dan peserta didik yang lebih aktif dalam pembelajaran. Hal ini tentunya mendukung dalam peningkatan pemahaman literacy skill yang menekankan pada pemahaman konsep ilmiah materi keanekaragaman hayati agar dapat lebih dimengerti oleh peserta didik.

\section{METODE}

Metode penelitian yang digunakan adalah (true experimental). Populasi dalam penelitian ini adalah seluruh kelas XI MIPA, sebanyak tujuh kelas. Sampel dalam penelitian ini diambil dengan menggunakan teknik cluster random sampling yang terdiri dari kelas eksperimen 1 dan kelas kontrol 1 . Instrumen penelitian yang digunakan dalam penelitian ini adalah tes scientific literacy skill sebanyak 32 butir soal. Desain penelitian yang digunakan pada penelitian ini adalah Pretest-posttest control group design (Creswell, 2015). Pola dari desain penelitian dirumuskan sebagai berikut:

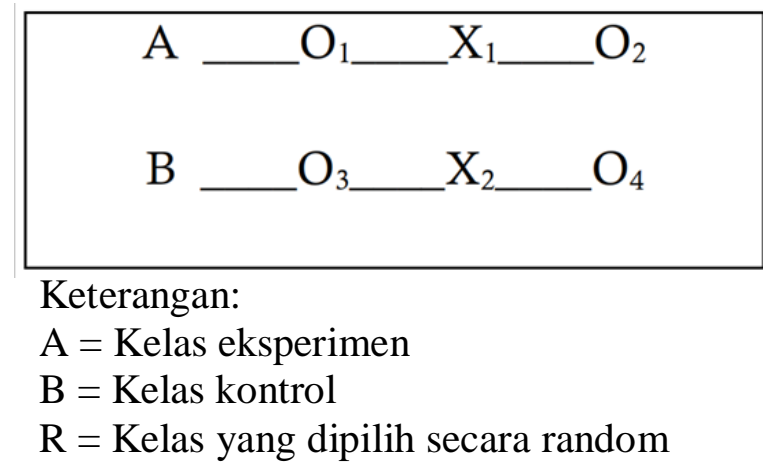


$\mathrm{O}_{1}=$ Pretest pada kelas eksperimen

$\mathrm{O}_{2}=$ Postest pada kelas eksperimen

$\mathrm{X}=$ Treatment dengan menggunakan model pembelajaran free inquiry

O3 $=$ Pretest kelas control

O4 = Postest kelas kontrol

Penelitian ini dilaksanakan sejak juni 2019 sampai oktober 2019 di suatu Sekolah Menengah Atas (SMA) Negeri dengan waktu tempuh kurang lebih 15 menit dari pusat kota. Data dianalisis dengan menggunakan uji prasyarat dan uji hipotesis. Uji normalitas dianalisis dengan uji chi kuadrat dan uji homogenitas dinalisis dengan uji $f$ maksimum. Hipotesis penelitian dianalisis dengan menggunakan uji $t$ independen.

\section{HASIL DAN PEMBAHASAN}

Data yang diperoleh dari penelitian ini adalah pretest dan posttest kelas eksperimen dan kontrol. Berdasarkan hasil uji prasyarat analisis yang telah dilakukan, seluruh data memenuhi prasyarat analisis yaitu data berasal dari populasi yang berdistribusi normal dan varians homogen. Uji $t$ independen digunakan untuk menguji hipotesis yang diajukan dalam penelitian. Tabel 1 disajikan ringkasan hasil uji hipotesis tersebut.

Tabel 1. Ringkasan Hasil Uji t

\begin{tabular}{ccc}
\hline Data & $\begin{array}{c}\text { Eksperimen } \\
\text { (free Inquiry) }\end{array}$ & $\begin{array}{c}\text { Kontrol } \\
\text { (direct intruction) }\end{array}$ \\
\hline Varians & 25,12 & 24,96 \\
Mean & 25,67 & 22,58 \\
$t_{\text {tabel }}$ & \multicolumn{2}{c}{2,02} \\
$t_{\text {hitung }}$ & \multicolumn{3}{c}{$-10,03$} \\
Kesimpulan & \multicolumn{2}{c}{ Tolak $\mathrm{H}_{0}$} \\
\hline
\end{tabular}

Berdasarkan hasil data ringkasan uji $\mathrm{t}$ pada tabel 1 dapat disimpulkan bahwa terdapat perbedaan pengaruh model free inquiry dan direct intruction terhadap scientific literacy skill peserta didik. Adapun perbandingan hasil rata-rata skor pretest-posttest dapat dilihat pada gambar 1. Gambar 1 menunjukkan bahwa $N$-gain kelas eksperimen dan kontrol masuk kategori sedang, namun kelas eksperimen mendapatkan nilai yang lebih tinggi. Hal ini menunjukkan bahwa kelas yang diajarkan dengan model pembelajaran free inquiry lebih baik dibandingkan dengan kelas yang diajarkan dengan model pembelajaran direct instruction.

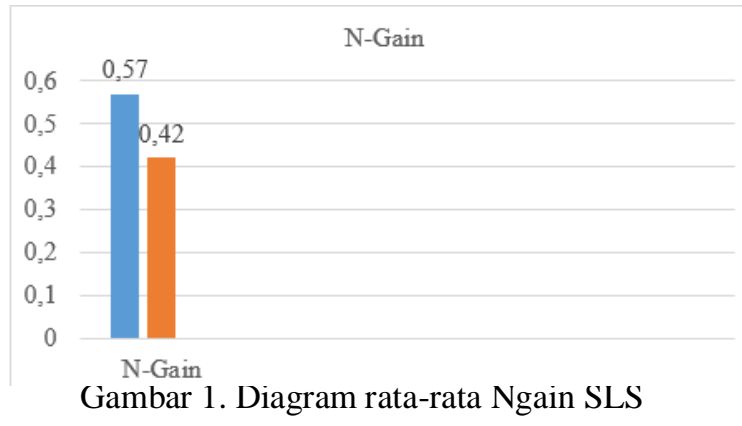

Dari gambar tersebut dapat dipaparkan bahwa nilai model free inquiry sangat berpengaruh terhadap scientific literacy skill, terlihat adanya perbedaan dengan kelas yang menggunakan metode pembelajaran direct intruction. Pada model free inquiry hasil pretest maksimum 29 dan postest maksimun 31, hasil pretest minimum 12 dan postest minimum 14. Sedangkan pada metode direct intruction nilai maksimum pretest 27 dan posttest 30 , sedangkan nilai minumum pretest 10 dan minimum postest 13. N-Gain eksperimen rata-rata 0,57 sedangkan $\mathrm{N}$ Gain komtrol rata- rata 0,42 . Berikut ini merupakan perolehan data hasil dari model pembelajaran free inquiry terhadap scientific literacy skill.

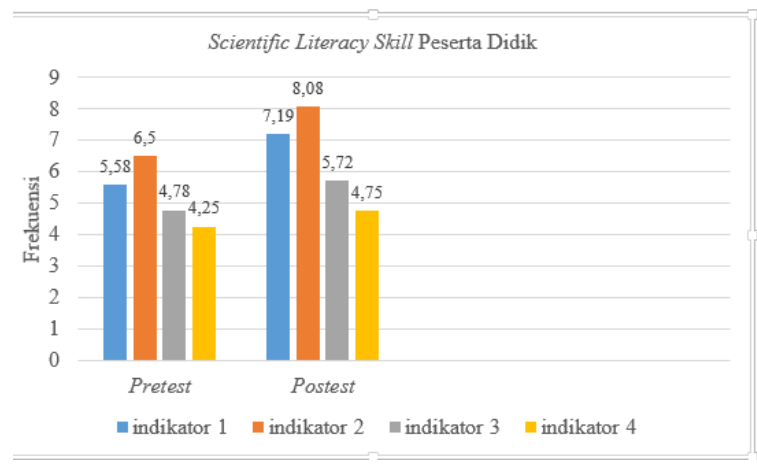


Gambar 2. Grafik perbandingan skor rata-rata pretest postest per indikator SLS menggunakan free inquiry

Berdasarkan Gambar 2 memperlihatkan data tertinggi skor pretest postest scientific literacy skill peserta didik terdapat pada indikator 2 yaitu menggunakan pencarian literatur yang tepat, yaitu sebesar 6,5, perolehan skor ini menunjukan kemampuan peserta didik pada indikator 2 dalam menggunakan pencarian literatur yang tepat, yaitu mampu mencari apa yang memenuhi syarat sebagai bukti dan hipotesis yang mendukung bukti ilmiah relative lebih tinggi dibandingkan indikator yang lain. Maka hasil penelitian yang dilakukan penulis bertolak belakang dengan penelitian yang dilakukan oleh Arohman, et.al. (2016) yang mengatakan bahwa "siswa cenderung lebih mampu mengolah data kuantitatif dibandingkan dengan memahami metode saintifik, hal ini disebabkan di sekolah keterampilan mengolah, menganalisis, serta menginterpretasikan data kuantitatif lebih sering digunakan karena terintegrasi dengan pelajaran lainnya (matematika)", yang artinya model free inquiry yang digunakan oleh penulis mampu meningkatkan pemahaman metode saintifik peserta didik.

Hal ini membuktikan bahwa kemampuan peserta didik dalam penguasaan model pembelajaran free inquiry di kelas eksperimen ini menunjukan kesesuaian dengan yang diharapkan oleh penulis, dikarenakan materi yang disajikan merupakan materi keanekaragaman hayati yang berkonsetrasi pada kebenaran suatu konsep ilmiah, disamping itu pengaruh model free inquiry yang selalu menekankan pada penguasaan konsep ilmiah peserta didik menjadikan skor pada indikator ini lebih tinggi. Menurut Hermawati (2012) pembelajaran dengan model inquiry menunujukan bahwa proses pembelajaran yang berlangsung berpusat pada siswa, siswa diberi kesempatan untuk terlibat secara aktif dalam belajar baik mental, intelektual dan sosial emosional. Sejalan dengan pernyataan Sanjaya (2009) kegiatan pembelajaran yang berlangsung melibatkan secara maksimal seluruh kemampuan siswa untuk mencari dan menyelidiki secafra sistematis, kritis, logis, analitis sehingga mereka dapat merumuskan sendiri penemuannya dengan penuh percaya diri. Sedangkan indikator 1,3 dan 4 yang merupakan indikator dari bagian metode ilmiah juga mendapatkan skor yang relatif tinggi walaupun mempunyai selisih, tapi hanya berkisar 1-2 perindikator.

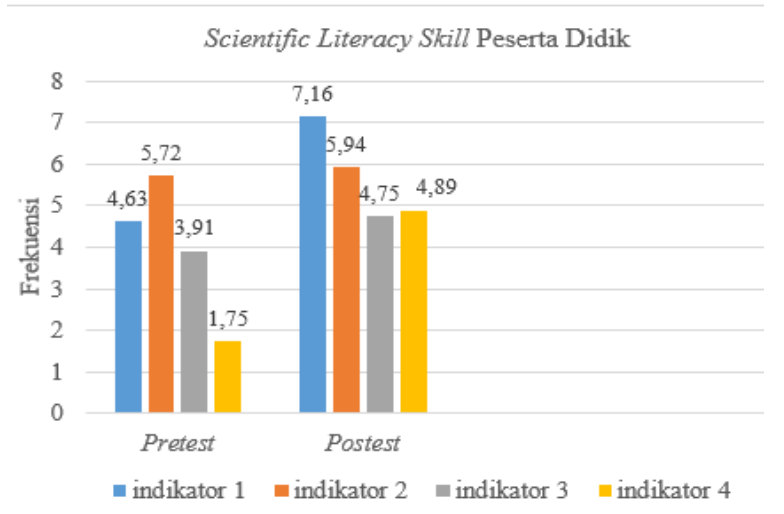

Gambar 3. Grafik perbandingan skor rata-rata pretest postest per indikator SLS menggunakan direct instruction

Berdasarkan gambar 3 memperlihatkan data tertinggi skor pretest posttest scientific literacy skill peserta didik, pada skor pretest terdapat pada indikator 2 menggunakan pencarian literatur yang tepat yaitu sebesar 5,72 dan skor terendah pada inidikator 4, memahami elemen desain penelitian dan dampak terhadap penemuan saintifik yaitu sebesar 1,75 .

Sedangkan data tertinggi skor posttest scientific literacy skill peserta didik terdapat pada indicator 1 mengidentifikasi argument saintifik yang tepat yaitu sebesar 7,16 dan skor terendah pada indikator 3, evaluasi dalam menggunakan informasi saintifik yang efektif yaitu sebesar 4,75. Dari data yang tersaji skor scientific literacy skill peserta didik hampir sama dengan kelas eksperimen akan tetapi 
perbedaan rentan skor perindikator dan skor total rata-rata scientific literacy skill (Gambar 3) antara kelas eksperimen cukup berbeda secara signifikan. Artinya dengan model direct instruction, scientific literacy skill masih dapat diukur akan tetapi tidak mengalami pencapaian seperti yang menggunakan model free inquiry. Menurut Sutopo, (2016) apapun tingkat sikap ilmiah siswa baik tinggi maupun rendah, siswa yang mempunyai kreatifitas tinggi tetap memperoleh prestasi belajar lebih tinggi baik nilai pengetahuan, nilai sikap, nilai keterampilan, dibandingkan siswa yang memiliki kreatifitas rendah. Hal ini sejalan dengan pernyataan Oullford (1968) dan Munandar (2004) bahwa siswa dengan kreatifitas tinggi akan lebih fleksibel, lebih lancer, lebih mandiri, berpikir orsinil dan mendasar, lebih elaborative, dan lebih realistis dalam mengikuti proses belajar.

Berdasarkan uraian tersebut dapat ditarik sebuah kesimpulan bahwa model free inquiry dapat meningkatkan dan memberikan pengaruh terhadap scientific literacy skill peserta didik pada materi keanekaragaman hayati.

\section{Proses Pembelajaran Scientific Literacy Skill Peserta Didik Kelas Eksperimen yang Menggunakan Model Pembelajaran Free Inquiry}

Berdasarkan hasil penelitian yang dilakukan di kelas eksperimen nilai rata-rata posttest scientific literacy skill adalah sebesar $(\overline{\mathrm{X}}=25,67)$ Sedangkan pada kelas kontrol nilai rata-rata posttest scientific literacy skill adalah sebesar sebesar $(\overline{\mathrm{X}}=$ 22,58). Berdasarkan data deskriptif tersebut dapat terlihat jelas perbedaan skor rata-rata antara kelas eksperimen dan kelas kontrol hal ini disebabakan karena perbedaan pengaruh perlakuan yang berbeda dalam penggunaan model pembelajaran. Kelas eksperimen memiliki proses pembelajaran yang menuntut serta didik untuk berfikir ilmiah karena dalam sintak ini terdapat merancang percobaan menurut Sudjana
(2014) sehingga peserta didik lebih memahami serta memiliki antusiasme yang tinggi dalam mencari materi, karena peserta didik diberikan keleluasaan penuh dalam mengakses informasi, memodifikasi konsep dan fenomena yang mereka temukan, serta menguhubungkan ke konsep lain agar terbentuk generalisasi konsep yang utuh sesuai tujuan pembelajaran. Hal itu sesuai dengan pendapat menurut PISA dalam Admoko (2010) "scientific literacy skill didefinisikan sebagai pengetahuan sains, penggunaan pengetahuan itu, untuk mengidentifikasi pengetahuan baru, menjelaskan fenomena sains dan menarik kesimpulan tentang sains yang berhubungan dengan isu-isu sehingga timbul ketersediaanya untuk terlibat dalam masalah yang terkait sains".

Model ini mempunyai karakteristik dan kerangka pembelajaran yang mendukung terpenuhinya indikatorindikator scientific literacy skill peserta didik sebagaimana dikemukakan oleh Huda (2015) bahwa "model pembelajaran ini didasarkan pada asumsi awal bahwa setiap manusia, termasuk peserta didik, merupakan konseptor alamiah". Dari pernyataan tersebut dapat dihubungkan bahwa Model Free Inquiry yang proses pembelajarannya menitikberatkan pada pemahaman sebuah konsep yang harus dipenuhi oleh peserta didik akan sejalan atau dapat memberikan dampak positif terhadap peningkatan scientific literacy skill yang menitikberatkan pada konsep atau pengetahuan alamiah. Arrahman et.al, (2016) dalam penelitiannya menyebutkan bahwa "Scientific literacy skill merupakan kapasitas untuk menggunakan pengetahuan ilmiah, mengidentifikasi pertanyaan dan menarik kesimpulan berdasarkan fakta dan data untuk memahami alam semesta dan membuat keputusan dari perubahan yang terjadi karena aktivitas manusia”. 
Oleh karena itu pemahaman sebuah konsep khususnya konsep pengetahuan ilmiah pada materi keanekaragaman hayati harus benar-benar dikuasai oleh peserta didik dengan menggunakan model yang cocok, karena pemahaman konsep merupakan hal yang diperlukan seperti dikatakan oleh Hamdani, Dedy, et.al. (2012) meyebutkan bahwa pemahaman konsep yang dimiliki oleh siswa dapat digunakan untuk menyelesaikan suatu permasalahan yang ada kaitan dengan konsep yang dimiliki, sehingga dalam pemahaman konsep siswa tidak hanya sebatas mengenal tetapi siswa harus dapat menghubungkan satu konsep dengan konsep lain. Berdasarkan uraian tersebut dapat disimpulkan bahwa model free inquiry merupakan salah satu model yang cocok digunakan dan memberikan dampak positif bagi scientific literacy skill khususnya pada materi keanekaragaman hayati yang selalu mengaitkan konsep dengan kehidupan nyata. Oleh karenanya model ini mempunyai pengaruh terhadap scientific literacy skill.

\section{Proses Pembelajaran Scientific Literacy Skill Peserta Didik Kelas Kontrol yang Menggunakan Model Direct Instruction}

Sementara itu dikelas kontrol menggunakan model direct instruction atau pembelajaran langsung model ini masih berfokus pada guru sehingga dalam proses pembelajaran peserta didik menjadi kurang aktif dan pembelajaran pun menjadi monoton. Proses pembelajaran peserta didik yang menggunakan model pembelajaran langsung cenderung membuat peserta didik menjadi kurang aktif karena guru menyampaikan materi secara langsung dan peserta didik hanya menyimak semua informasi dari guru. Sehingga peserta didik cepat merasa bosan dan kurang termotivasi untuk mengikuti pembelajaran yang disampaikan guru.

Menurut Joyce dan Weill (2009) menyatakan bahwa tujuan utama model direct instruction adalah untuk memamksimalkan penggunaan waktu belajar peserta didik. Bahkan menurut Arends (1997) dalam SaktiC(2012) model pembelajaran langsung adalah salah satu pendekatan mengajar yang dirancang khusus untuk menunjang proses belajar siswa yang berkaitan dengan pengetahuan deklaratif dan pengetahuan procedural yang terstruktur dengan baik, yang dapat diajarkan dengan pola kegiatan tang bertahap, selangkah demi selangkah, terstruktur, mengarahkan kegiatan para siswa, mempertahankan fokus pencapaian akademik.

Model pembelajaran langsung mengawali pembelajaran dengan menyampaikan tujuan pembelajaran, selanjutnya sebelum mengerjakan lembar kerja guru menyampaikan terlebih dahulu materi secara langsung dan peserta didik hanya menyimak dengan baik. Kemudian setelah materi selesai disampaikan guru membagi peserta didik dalam beberapa kelompok secara heterogen dan membagikan lembar kerja peserta didik, setelah itu guru membimbing peserta didik dalam proses diskusi dimulai dari perumusan sampai penyelesaian masalah yang disajikan pada lembar kerja. setelah selesai peserta didik mempresentasikan hasil diskusinya dan terakhir peserta didik dan guru bersamasama melakukan tanya jawab dan menyimpulkan pembelajaran yang telah dilaksanakan.

Dalam pelaksanaan model pembelajaran langsung tentunya mempunyai kekurangan yaitu pada proses 
pembelajaran peserta didik yang menggunakan model pembelajaran langsung cenderung membuat peserta didik menjadi kurang aktif dan berpikir secara monoton, karena guru menyampaikan materi secara langsung sehingga peserta didik tidak terlatih untuk berpikir kritis dan berpikir ilmiah dalam penyelesaian masalah yang disajikan karena peserta didik sudah dibekali dengan materi yang telah diterangkan sehingga peserta didik cenderung menyelesaikan masalah dengan informasi yang telah ada dan tidak ada motivasi untuk mencari dan menganalisa masalah. Selain itu proses pembelajaran dikelas cenderung lebih pasif, cepat bosan dan jenuh dengan kegiatan pembelajaran. Oleh karena itu tidak sedikit peserta didik yang mencari kesibukan lain seperti dengan mengobrol sehingga hasil belajar peserta didik kurang memuaskan karena peserta didik hanya menemukan pemahaman materi dari yang di sampaikan guru.

Sedangkan kelebihan pada pembelajaran langsung materi dapat tersampaikan secara merata dan tersusun dalam model pembelajaran langsung, guru mengendalikan isi dan urutan materi yang diberikan, sehingga dapat mempertahankan fokus mengenai apa yang harus dicapai peserta didik, selain itu model pembelajaran langsung juga dapat menjadi cara untuk menyampaikan informasi yang banyak dalam waktu yang relatif singkat.

\section{SIMPULAN}

Berdasarkan hasil analisis data dan pengujian hipotesis, maka diperoleh simpulan ada pengaruh model pembelajaran free inquiry terhadap scientific literacy skill peserta didik pada materi Keanekaragaman Hayati studi eksperimen di kelas X MIPA Negeri 6 Kota Tasikmalaya tahun ajaran 2019/2020. Berdasarkan simpulan dari hasil penelitian sebagaimana disebutkan di atas, penulis mengajukan saran-saran sebagai berikut:

1. Diperlukan persiapan yang matang dalam melaksanakan pembelajaran, khususnya pembelajaran dengan menggunakan model free inquiry, sehingga dalam pelaksanaannya guru dan peserta didik dapat memaksimalkan langkah-langkah pembelajaran agar sesuai dengan yang diharapkan;

2. Diharapkan pada setiap proses pembelajaran hendaknya menggunakan berbagai macam model pembelajaran yang bervariasi disesuaikan dengan materi yang akan dipelajari atau disampaikan

3. Diharapkan mampu menerapkan model pembelajaran free inquiry terhadap materi yang lain.

\section{DAFTAR PUSTAKA}

Arohman, et.al. (2016). "Kemampuan Literasi Sains Siswa Pada Pembelajaran Ekosistem". Proceeding Biology Education Conference. 13(1), 90-92. Bandung. Creswell, Jhon W. (2015). Research Design Pendekatan Kualitatif, Kuantitatif, dan Mixed. Yogyakarta: Pustaka Pelajar.

Hamdani, Dedy. (2012). "Pengaruh Model Pembelajaran Generatif dengan Menggunakan Alat Peraga terhadap Pemahaman Konsep Cahaya Kelas Viii Di Smp Negeri 7 Kota Bengkulu". Jurnal Excata. 10(1), 1412-3617. Bengkulu. 
Hermawati, Wayan Manik (2012).

Pengaruh Model Pembelajaran

Inkuiri Terhadap Penguasaan

Konsep Biologi dan Sikap Ilmiah

Siswa SMA Ditinjau dari Minat

Belajar Siswa. Jurnal

Huda, Miftahul. (2014). Model-

Model Pengajaran dan

Pembelajaran. Yogyakarta: Pustaka

Pelajar.

Joyce, Bruce, et.al. (2015). Models of

Teaching, Model - model

Pengajaran. Yogyakarta: Pustaka Pelajar.

Kurniasih, I, Berlin. 2015. Ragam Pengembangan Model

Pembelajaran Untuk Peningkatan Profesionalitas Guru.

Sakti, Indra dkk. (2012). Pengaruh Model Pembelajaran Langsung Melalui Media Animasi Berbasis Macromedia Flash Terhadap Minat Belajar dan Pemahaman Konsep Fisika Siswa di SMA Plus Negeri 7 Kota Bengkulu. Jurnal exacta, Vol.10 No 1, Halaman 2. 